folk/ed. Derg, 2020; 26(1): 87-113

DOI: $10.22559 /$ folklor.1132

\title{
Kırım Karay Türkleri Arasında Köroğlu Destanının İzleri
}

\section{Epic of Koroghlu Traces Between Crimean Karay Turks}

\section{Fatih Şayhan*}

Öz

Türk destancılık geleneğinin en önemli anlatmalarından olan Köroğlu Destanı, Türkistan'dan Balkanlar'a kadar Türk kültür coğrafyasının hemen hemen tamamında yer edinmiştir. Bunda şüphesiz ki, Türk insanının tarihsel süreç içerisinde birbirinden farklı ve çok uzak coğrafyalarda yaşamış olsa da en önemli tarihsel varlık alanı olan dilinin birleştirici ve eriştirici yönünün payı büyüktür. Bu bakımdan Türk dünyası coğrafyası içerisinde aktarım ve yayılma bakımından en çok kültürel çeşitliliğe uğrayan anlatıların başında Köroğlu Destanı gelir. Köroğlu Destanı, Kırım Karay Türkleri arasında da kendisine yer edinmiş; Kırım Karay Türklerinin "mecuma” adını verdiği İbrani harfli matbu basımlı bir mecmuada Köroğlu'na ait halk şiirlerinin bulunduğu tarafımızdan gözlemlenmiştir. Museviliğin Karaizm mezhebine mensup olan Karay Türkleri, sözlü gelenek içerisinde yaşattıkları halk edebiyatı yaratmalarını yazının gücü ile birleştirmiş ve "mecuma" adını verdikleri mecmualara aktarmışlardır. Bu çalışma ile birlikte Kırım'ın Kezlev şehrinde S, Şapşal tarafından kurulan Karay kütüphanesinden alınan matbu bir mecmuada geçen "Kör Oglı" başlıklı 20 şiir İbrani harflerinden Latin harflerine aktarılarak Türkoloji sahasına kazandırılması amaçlanmıştır.

Anahtar sözcükler: Türk dünyast, Kırım Karay Türkleri, mecmua, Köroğlu destanı, eş metinler

Geliş tarihi (Received): 11 Nisan 2019 - Kabul tarihi (Accepted): 13 Ekim 2019

* Dr. Öğr. Üyesi, Ardahan Üniversitesi İnsani Bilimler ve Edebiyat Fakültesi. Türk Dili ve Edebiyatı Bölümü. Türk Halk Edebiyatı Anabilim Dalı. fatihsayhan@ardahan.edu.tr. ORCID ID 0000-0002-8592-3490. 


\begin{abstract}
The epic of Koroghlu, one of the most important narratives of The Turkish epic tradition, has been taken place in almost all of the Turkish cultural geography from Turkistan to the Balkans. Undoubtedly that Turkish people lived in different and very distant regions in the historical process, but language is the most important assembly historical factor. In this respect, Koroghlu Epic is one of the narratives which have been subjected to the most cultural diversity in terms of transference and spread within the geography of the Turkish world. The Epic of Koroghlu has also taken a place among the Crimean Karay Turks; It has been observed in a printed journal with Hebrew letters by us that there were folk poems of Koroghlu. Karay Turks who are belonged to the Karaism sect of Judaism, has combined their creations of folk literature with the power of writing and transferred them to the magazines that they called 'mecuma'. In this study, 20 poems 'Kör Oglı' titled in a magazine taken from Karay library founded by S, Şapşal in Crimea Kezlev city aimed to be transferring to the field of Turkology by transferring from Hebrew letters to Latin letters.
\end{abstract}

Keywords : Turkish world, Crimean Karay, mecmua, epic of Koroghlu, peer text

\title{
Giriş
}

Türk anlatı geleneği, değişen/dönüşen dünyanın ruhunu okuma noktasında, çağın ruhuna uygun karakter yaratma ve yaratmış olduğu karakterlere doğal bir canlılık kazandırabilme yetisi bakımından dünya anlatı geleneğinin zirve noktasındadır. Bireyi ve ait olduğu toplumu ruhsal dönüşüm çizgisi üzerinden okumanın metne yansıyan yüzü olan bu anlatılar, zaman içerisinde gelişen sosyolojik olgular neticesinde bir değişim/dönüşüm çizgisine uğrasa da özünde Türk anlatı geleneğinin özgün karakter yaratma ve karakterlere doğal akıcılık katma gücünü ortaya koymaktadır. Bunda şüphesiz Türk kolektif ruhunun ifade gücünü, sanatın her türü ile ortaya koyma yetisinin payı büyüktür. Nitekim yaratılan her bir halk anlatması toplum tarafından zaman içerisinde çağlar ötesi bir dile kavuşturulmuş ve tüm insanlığın ortak hazinesine sunulmuştur.

Türk anlatı geleneği göz önünde bulundurulduğunda; herhangi bir halk anlatmasının bir yerden başka bir yere sözlü veya yazılı bir şekilde taşınabildiği ve bu taşınma esnasında anlatının kültürel bellekte çeşitlenme kazandığı pek çok halk anlatmasında görülmektedir. Mitolojik düzlemde ortaya çıkan anlatılar, tarihin aynalarından toplumların yaşam karşısındaki kökensel dinamikleri hakkında gerçeklikler sunar. Bu bağlamda Türk kolektif ruhu kendisini şimdide güncelleme ve anlatı kahramanlarına yeni boyut kazandırma noktasında oldukça derin bir kültürel sese sahiptir. Nitekim evreni ve yaşamı yeniden anlamlandırma sürecinde evrenin yenilenmesi ve sürdürülebilirliğine anlam katmaya yönelik sözün gücü ile birleştirilen anlatılardan bir tanesi de Köroğlu Destanı'dır. Bu bakımdan Türk dünyası içerisinde aktarım ve yayılma bakımından en çok kültürel çeşitliliğe uğrayan anlatıların başında Köroğlu Destanı gelir. ${ }^{1}$ Nitekim Köroğlu, Türkistan'dan Balkanlar'a kadar Türk kültür coğrafyasının tamamında tespit edilebildiği gibi aynı zamanda canlıcılık esasına dayalı Türk kültürü ile etkileşim içinde olan diğer topluluklarda da gözlemlenmektedir. Bunda şüphesiz Türk insanının, birbirinden çok uzak coğrafyalarda yaşamış olsa da en önemli tarihsel varlık alanı 
olan dilinin birleştirici ve eriştirici özelliği sayesinde kültürel zenginliğini yaşatarak gelecek nesillere aktarma çabasının payı büyüktür.

Boratav, halk hikâyelerinde musanniften ya da hikâyeye mevzu olmuş ve hakikaten yaşamış âşıklardan kalan tek unsurun nazım kısmı olduğunu söyler. Nitekim lirik değeri yüksek olan parçaların halk hikâyelerinin içinden ayrılıp halk türküsü olarak yayılabileceğini ve cönklere geçebileceğini ifade ederek Köroğlu'nun cenk türkülerinin de hikâyelerinden müstakil olarak, sözlü hikâye geleneğinin zayıfladığı veya kaybolduğu yerlerde yayılmış olduğunu ve canlılığını koruduğunu vurgular (Boratav 2011: 75-76). Farklı coğrafyalarda yaşasalar da ortak duygu ve düşüncelerle hareket eden Türk topluluklarının sözlü kültür ürünlerinde bu benzerliklerin olması son derece doğaldır. Çünkü yaratmış olduğu kahramana doğal bir canlılık kazandıran Türk biliş sistemi, o kahramanı sosyal, siyasî ve kültürel hayatının her safhasına yerleştirerek geniş bir yayılma sahası kazandırmıştır.

Türk dünyası epik anlatım ürünlerinin en önemlilerinden olan Köroğlu, Kırım Karay Türkleri arasında da kendisine yer edinmiş; Kırım Karay Türklerinin “mecuma” adını verdiği İbrani harfli matbu basımlı bir mecmuada Köroğlu’na, Âşık Ömer’e ve Gevheri’ye ait halk şiirlerinin bulunduğu tarafımızdan gözlemlenmiştir. Nitekim incelemeye esas aldığımız matbu basımlı mecmua, Erdoğan Altınkaynak tarafından 2003 yılında Kırım’ın Kezlev şehrinde S. Şapşal tarafından kurulan milli "Karay-Bitikliğii” kütüphanesinden (Altınkaynak 2006: 29) temin edilmiştir. Mecmua toplam 424 sayfadan oluşmakta olup mecmuanın ilk 85 sayfası elimize geçmemiştir. Mecmuanın 260-270. sayfaları arasında "Kör Oglı" başlığı altında 20 adet şiir çeviri yazı esasına dayanarak İbrani harflerinden Latin harflerine aktarılmıştır. Şiirlerin çeviri yazı esasına dayanarak aktarımı hususunda metne sadık kalınmış ve okunmayan kısımlar (...) şeklinde belirtilmiştir. Yine okuma işaretlerinin noksanlığından dolayı birden fazla kelimeyi karşılayan kısımlar (/) işareti ile gösterilmiştir. Aktarmış olduğumuz şiirlerde geçen kişi ve yer adları ise şiir numaraları ile birlikte şu şekildedir:

\begin{tabular}{|l|l|}
\hline \multicolumn{1}{|c|}{ Kişi Adları } & \multicolumn{1}{c|}{ Yer Adları } \\
\hline $\begin{array}{l}\text { Köroğlu }(12,13,14,15,16,17,18,22,23,24,25, \\
26,28,31,32,33)\end{array}$ & Anadolu (16) \\
\hline Ayvaz $(14,19,21,23,24,25)$ & Çamlıbel (16, 18, 19, 25, 31, 32) \\
\hline Bolu Beyi $(16,24)$ & Çardaklı (26) \\
\hline Telli Hanım $(12,13,24)$ & İstanbul (17) \\
\hline Cevher Paşa $(13)$ & Gürcistan (19) \\
\hline Demirci $(12,17,21,22)$ & Erzurum (12) \\
\hline Bezirgan $(14,18,19,22,32)$ & Arabistan (18, 22, 33) \\
\hline Hıdır Oğlu Mustafa (22, 26) & Dağıstan (25) \\
\hline Hacı Osman (21) & Edirne (23) \\
\hline Reyhan Arap (21) & Kasımpaşa (17) \\
\hline Laz, Türkmen, Arap, Kürt (14, 22, 32, 33) & Hint, Urum, Yemen, Şam (14, 15) \\
\hline
\end{tabular}


Metinler

$$
\text { 12) כור אוגלי }
$$

דמירגי אוגלי ארוורומא וארן דא : ואריפ איםפהאהיליכ סטמגיג גרכ :

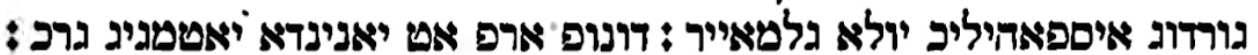

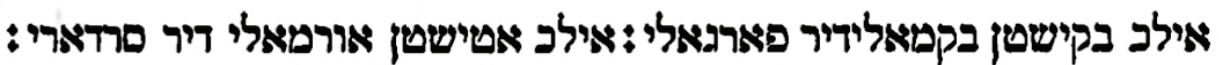

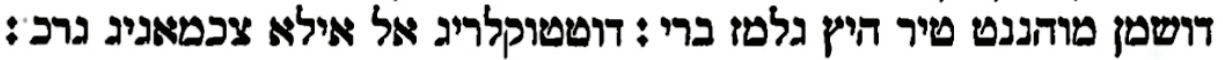

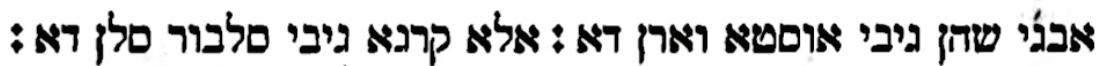

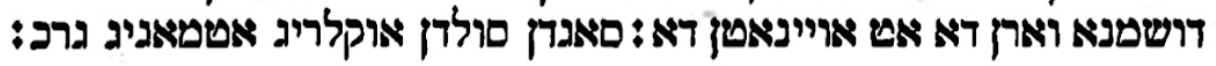

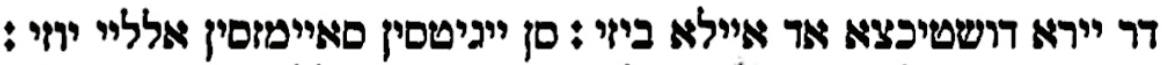

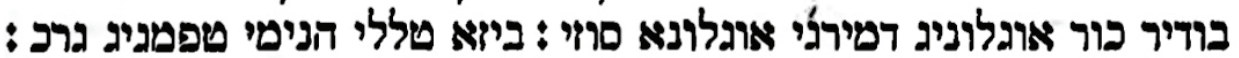

\section{2) KÖR OGLI}

Demirci oglı İrzurum'a varan da

Varıp ispahilik satmagıñ gerek

Gördüñ ispahilik yola gelmeyir

Dönüp Arap at yanında yatmagıñ gerek

İlk bakıştan bakmalıdır Pargalı

İlk atıştan urmalıdır serdarı

Düşman muhannettir hiç gelmez beri

Duttuklarıñ el ile çekmegiñ gerek

Avcı şahan gibi üste varan da

Ala karga gibi salbur salan da

Düşmana varan da at oynatan da

Sagdan soldan oklarıñ atmagıñ gerek

Der yire düştikçe ad eyle bizi

Sen yigitsin saymazsın elliyi yüzi

Budır Kör Oglu'nıñ ogluna sözi

Bize Telli Hanım'ı tapmagıñ gerek 


\section{3}

ג'ודר פשאם בוגון דוגיש גונידיר : כסיליפ כללאלר פיאי פיידנדא דורסון:

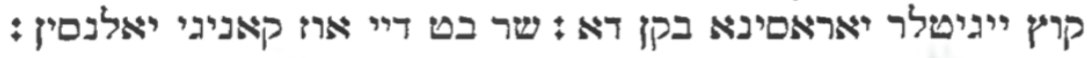

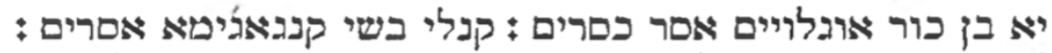

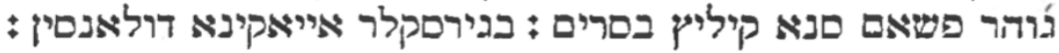

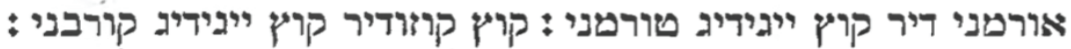

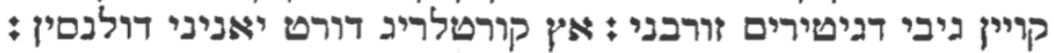

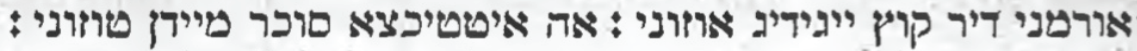

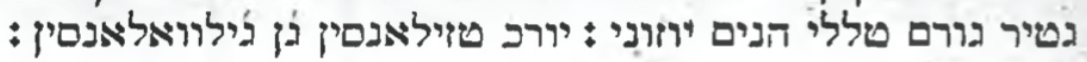

\section{3) KÖR OGLI}

Cevher Paşa'm bugün dögiş günidir

Kesilip kelleler miydanda dursun

Koç yigitler yarasına bakan da

Şer bet deyi ün kanını yalansın

Ya ben Kör Oglu’yım asar keserim

Kanlı başı kangacıma asarım

Cevher Paşa'm sana kılıç basarım

Bagırsaklar ayakına dolansın

Ormanıdır koç yigidiñ türmeni

Koç kuzudır koç yigidiñ kurbanı

Koyın gibi dagıtırım zurbanı/zürbeni

Aç kurtları̃ dört yanını dolansın

Urmanidir koç yigidiñ uzunı

Ah ittikçe söker miydan tozunı

Getir görem Telli Hanım yüzüni

Yürek tazilensin can cilvelensin 


\section{4 כור אוגלו}

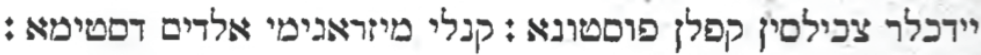

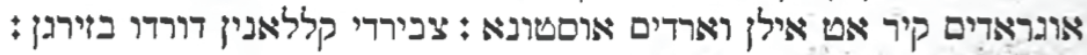
בירגן גורט אוגלו דיר גורנלר ששר : ארקרדשי גורטטיר גנדינא אוקשאר :

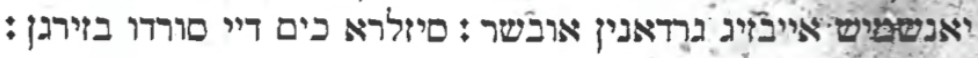
אסלא סיכֹמו אידים אורומי שאמי : מסללרי אםלן גיבי קורדו בזירגן:

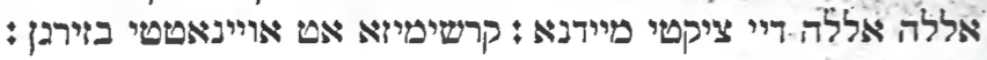

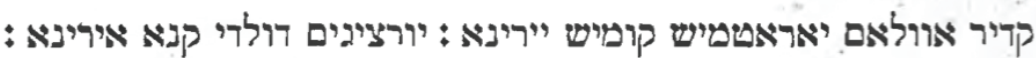
אוץ כרט סאבאש איטטיכ בירי בירינא : בני אטטן אשדא יוראי אלדי בוירגן:

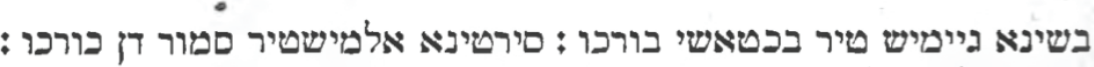
כור אוגלי סוולאדי אונדא ביר טורכו : ביג בש יוו טומנני סאיידי בזירגן:

\section{4) KÖR OGLI}

Yidekler çekilsin kaplan postuna

Kanlı mızragımı aldım destime

Ugradım kır at ilen vardım üstüne

Çevirdi kallagın durdu bezirgan

Bezirgan Gürt ogludır görenler şaşar

Arkardaş1 Gürt'tir gendine okşar

Yanaşmış Ayvaz'ın gerdanın ovşar

Sizlere kim deyi sordu bezirgan

Asla sivmez idim Urum'1 Şam'1

Masalları aslan gibi kurdu bezirgan

Allah Allah deyi çıktı miydana

Karşımıza at oynattı bezirgan

Kadir Mevlam yaratmış komış yerine

Yüreçigim doldı kana irine

Üç keret savaş ittik biri birine

Beni attan aşaha aldı bezirgan

Başına giymiştir Bektaşi börkü

Sırtına almıştır samurdan kürkü

Kör oglı sevledi onda bir türkü

Biñ beş yüz tümenni saydı bezirgan 
15) פור אווגלו

כור אוגליני בילמאייאן נשי דיר נשי : מוהננט מיידנינדא גםטיריר בשי פירי :

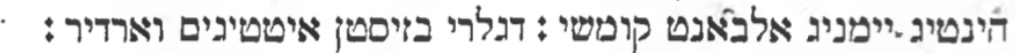

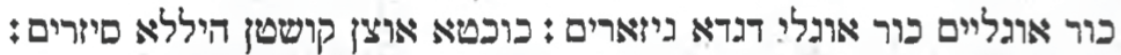

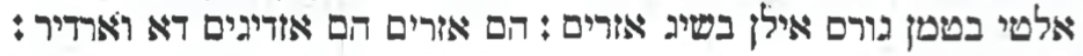

ואר גיט איגלאן ואר גיט יולוגדן דונמא : אוליר אולמו מוהננטי דוסט אוליר

סנמא:

דושמן דן קורקופ גרייא דונמא : ייגידיג בשינא יאזילן וארדיר :

\section{5) KÖR OGLI}

Kör oglını bilmeyen naşidir naşi

Muhannet miydanında gestirir başı

Hint'iñ Yemen'iñ alvant komş1

Dağları bezistan ittigim yerdir

Kör oglıyım Kör oglı dagda gizerim

Kökte uçan kuştan hile sizerim

Altı batman gürs ile başıñ ezerim

Hem ezerim hem ezdigim de vardır

Var git oglan var git yolundan dönme

Olır olmaz muhanneti dost olır sanma

Düşmandan korkup geriye dönme

Yigidiñ başına yazılan vardır 


\section{6) בור אוגלי}

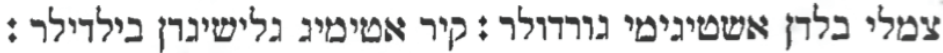

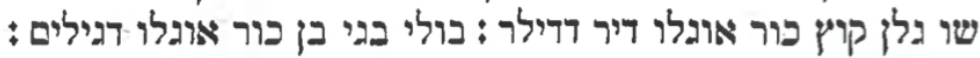

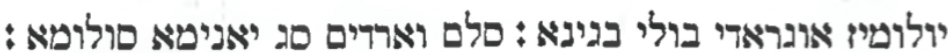

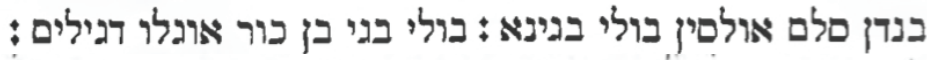

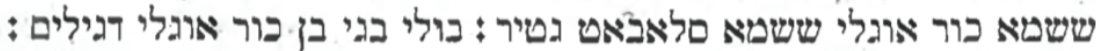

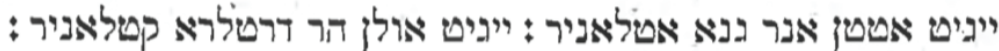

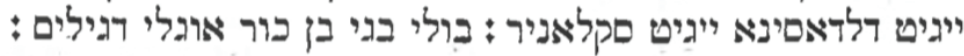

ייגיט אולן אוקין אמר יאיינדן : ייגיט אולדיר גנדי גנדין באיידין :

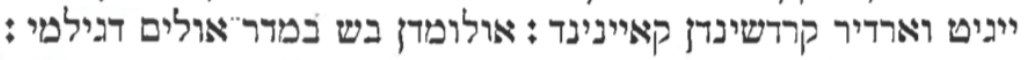

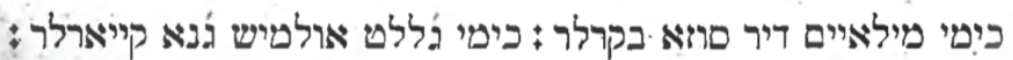

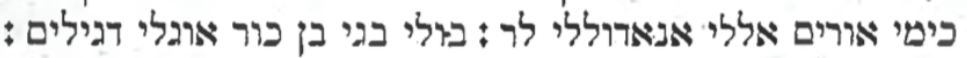

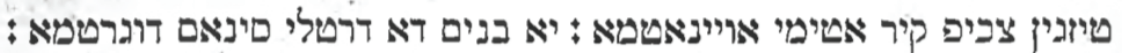
אלים בגלי דוסט יווניא אוגראטמא: בולי בגי בן כור אוגלי דגילים :

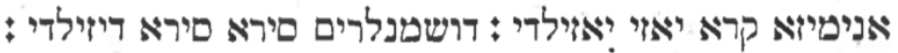

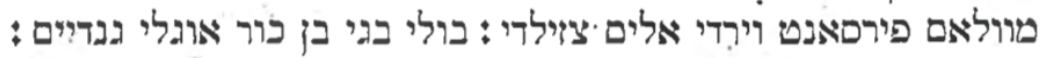

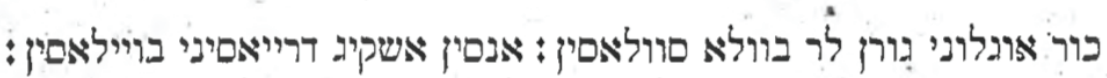

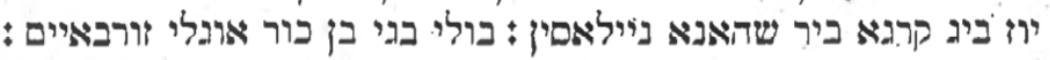

\section{6) KÖR OGLI}

Çamlıbelden aştıgımı gördüler

Kır atımıñ gelişinden bildiler

Şu gelen koç Kör ogludır dediler

Bolı begi ben Kör oglu degilim

Yolumız ugradı Bolı begine

Selam verdim sag yanıma soluma

Benden selam olsın Bolı begine

Bolı begi ben Kör oglu degilim

Şaşma Kör oglı şaşma salavat getir

Bolı begi ben Kör oglu degilim 
Yigit attan iner gene atlanır

Yigit olan her dertlere katlanır

Yigit daldasında yigit saklanır

Bolı begi ben Kör oglu degilim

Yigit olan okın emer yayından

Yigit oldır gendi gendin bayıdan

Yigit vardır kardaşından kaynından

Bolı begi ben Kör oglu degilim

Kimi milayimdir söze bakarlar

Kimi cellat olmış cana kıyarlar

Kimi Urım elli Anadollılar

Bolı begi ben Kör oglu degilim

Tizgin çekip Kır atımı oynatma

Ya benim de dertli sinem dogratma

Elim baglı dost yüzüne ugratma

Bolı begi ben Kör oglu degilim

Anımıza kara yazı yazılır

Düşmanlarım sıra sıra dizilir

Mevlam firsant virdi elim çözilir

Bolı begi ben Kör oglu degilim

Kör oglunı görenler bevle sevlesin

Ensin aşkıñ deryasını boylasın

Yüz biñ karga bir şahana neylesin

Bolı begi ben Kör oglu degilim 


\section{7}

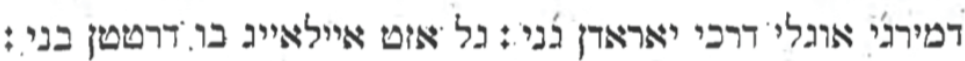

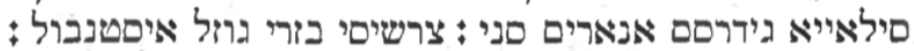

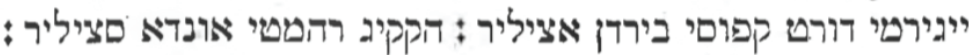

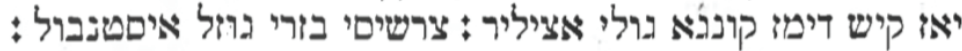

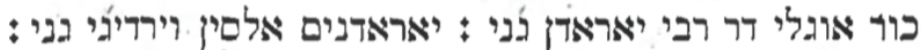

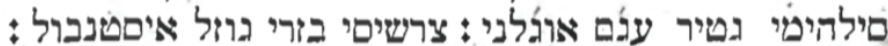

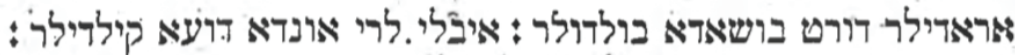

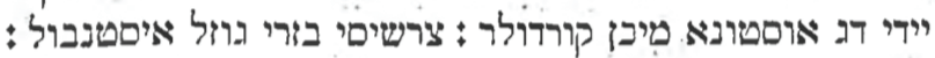

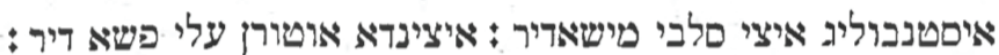

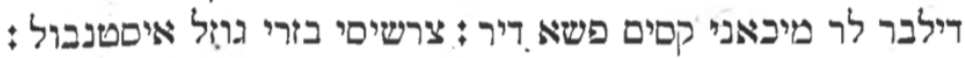

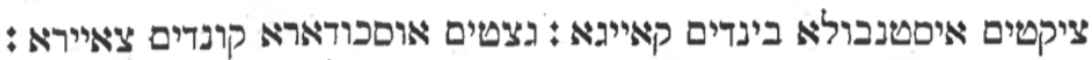

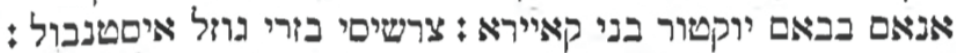

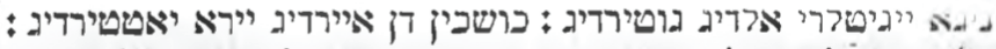

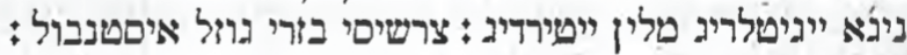

\section{7) KÖR OGLI}

Demirci oglı der ki yaradan canı

Gel azat eyleyiñ bu dertten beni

Sılaya gidersem anarım seni

Çarşısı bazarı güzel İstanbul

Yigirmi dört kapusı birden açılır

Hakkıñ rahmeti ondan saçılır

Yaz kış dimez konca güli açılır

Çarşısı bazarı güzel İstanbul

Kör oglı der rabbi yaradan canı

Yaradanım alsın virdigi canı

Silahımı getir Acem oglanı

Çarşısı bazarı güzel İstanbul

Aradılar dört köşede buldular

İvlileri onda du'a kıldılar

Yidi dag üstüne mikan kurdular

Çarşısı bazarı güzel İstanbul 
İstanbulıñ içi selbi mişedir

İçinde oturan 'ali paşadır

Dilberler mikanı Kasımpaşa’dır

Çarşısı bazarı güzel İstanbul

Çıktım İstanbul'a bindim kayıga

Geçtim Üsküdar'a kondım çayıra

Anam babam yoktur beni kayıra

Çarşısı bazarı güzel İstanbul

Nice yigitleri aldıñ götirdiñ

Köşkinden ayırdın yire yettirdiñ

Nice yigitleriñ malın yetirdiñ

Çarşısı bazarı güzel İstanbul

18 בור אוגלי

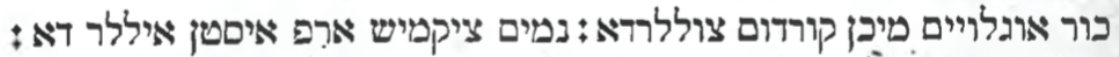

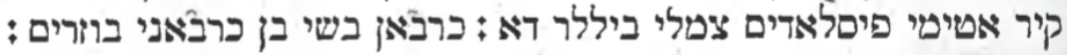

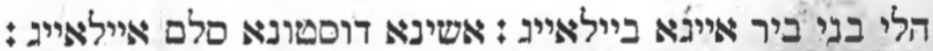

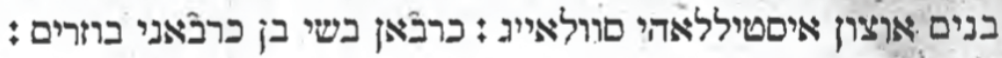

סן צוגא גוואניפ גנדיני אטמא : מוולאיי סיברסג. בני דרילטמא:

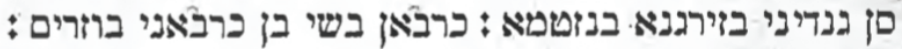

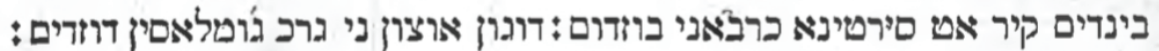

קיר אטים יורולדי כפימי בוזדום : אמן קיר אט צמלי בילא יירישטיר :

\section{8) KÖR OGLI}

Kör ogluyım mikan kurdum çöllerde

Namım çıkmış Arapistan illerde

Kır atımı fısladım Çamlıbillerde

Kervan başı ben kervanı bozarım

Heli beni bir eyice biyleyin

Eşine dostuna selam eyleyin

Benim üçün istillahı sevleyiñ

Kervan başı ben kervanı bozarım 
Sen çoga güvenip gendini atma

Mevlayı siverseñ beni darıltma

Sen gendini bezirgana benzetme

Kervan başı ben kervanı bozarım

Bindim Kır at sırtına kervanı bozdum

Dügün üçün ni gerek cümlesin düzdüm

Kır atım yoruld kefimi bozdum

Kervan başı ben kervanı bozarım

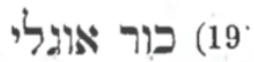

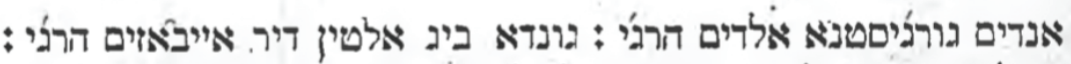

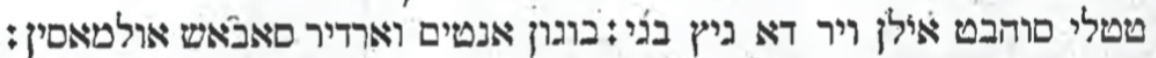

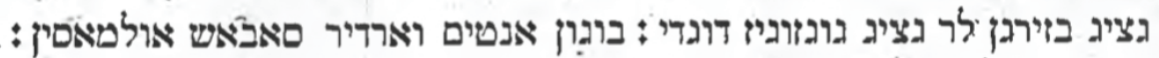

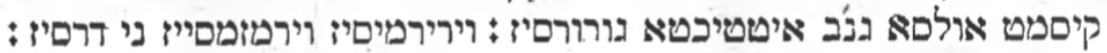

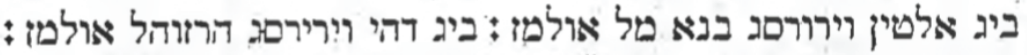

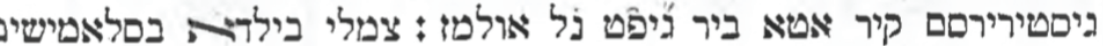

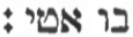

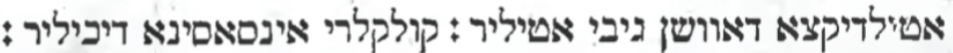
ביםאטליק דא ביג אלטינא סטיליר : צמלי בילדא בסלאטישים בו אטירי :

\section{9) KÖR OGLI}

Endim Gürcistan'a aldım haracı

Günde biñ altındır Ayvaz'ım haracı

Tatlı sohbet ilen vir de giç bac1

Bugün antım vardır savaş olmasın

Geçiñ bezirganlar geçiñ gögzügiz dogdı

Bugün antım vardır savaş olmasın

Kısmet olsa cenk ittikte görürsiz

Virir misiz virmez misiz ni dersiz

Biñ altın virürseñ bana mal olmaz

Biñ dahi virirseñ harzuhal olmaz

Gistirirsem kır ata bir cift nal olmaz

Çamlı belde baslamışım bu atı 
Atıldıkça davşan gibi atılır

Kulakları insesine dikilir

Kisatlıkda biñ altına satılır

Çamlıbelde baslamışım bu atı

20 כור אוגליל

ביר מורדים ואר קיר אט סניג יאנינא: קיר אט בני מורדימא יירישטיר :

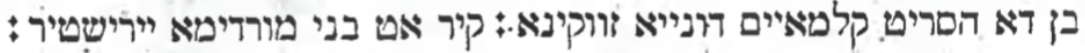

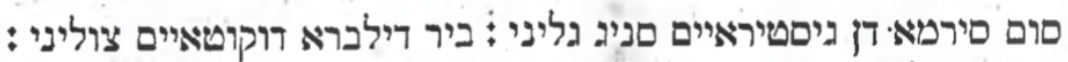

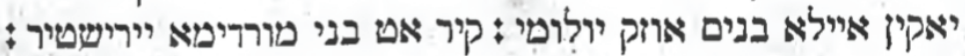

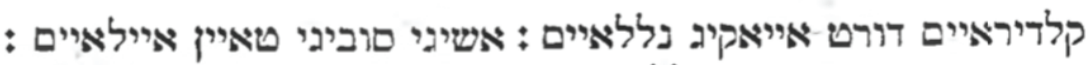

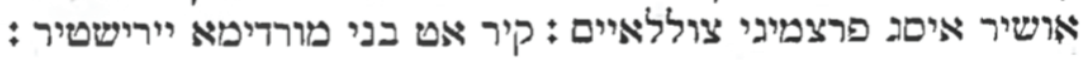

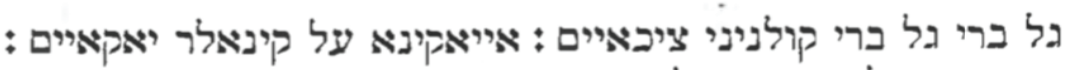

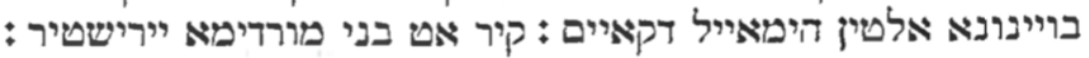

\section{0) KÖR OGLI}

Bir muradım Kır at seniñ yanına

Kır at beni muradıma yeriştir

Ben de hasrit kalmayım dünya zevkine

Kır at beni muradıma yeriştir

Som sırmadan gistireyim seniñ nalını

Bir dilbere dokutayım çulını

Yakın eyle benim benim uzak olmaz

Kır at beni muradıma yeriştir

Kaldırayım dört ayakıñ nallayım

Aşı1gı subıgı tayin eyleyim

Üşir iseñ perçemiñi çullayım

Kır at beni muradıma yiriştir

Gel beri gel beri kulagını çikeyim

Ayakına 'al kınalar yakayım

Boynuna altın himayil dakayım

Kır at beni muradıma yiriştir 


\section{1) כור אוגלי}

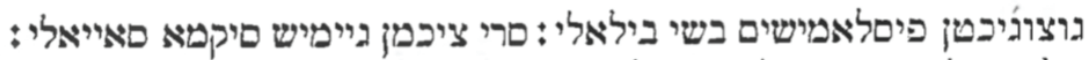

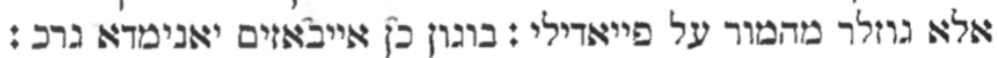

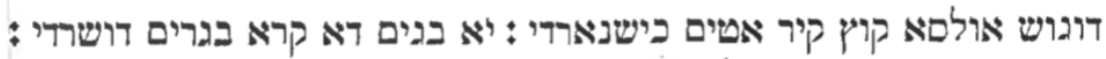

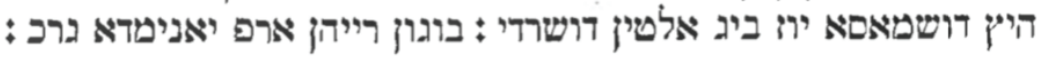

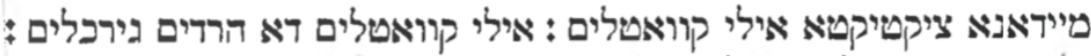

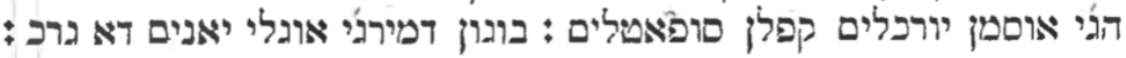
טאוולא דא פיסלאנן ארביג אטי :אסלא קוץץ גרכ טיר ייגידיג ואטי :

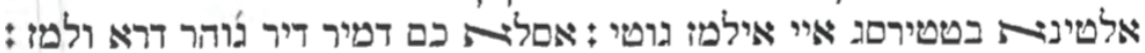

\section{1) KÖR OGLI}

Güçücikten fislamışım başı bilalı Sarı çikmen giymiş sıkma sayeli Ala gözler mahmur 'al payedili Bugün Han Ayvaz’ım yanımda gerek

Dögüş olsa koç kır atım kişnerdi Ya beñim de kara bagrım düşerdi Hiç düşmese yüz biñ altın düşerdi Bugün Reyhan Arap yanımda gerek

Miydana çıktıkta ili kuvetlim İli kuvetlim de herdim gireklim Hacı Osman yüreklim kaplan sufatlım Bugün Demirci oglı yanımda gerek 


\section{2 בור אוגלי}

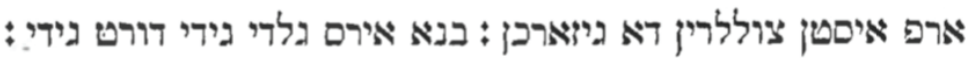

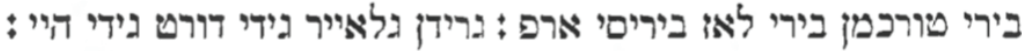

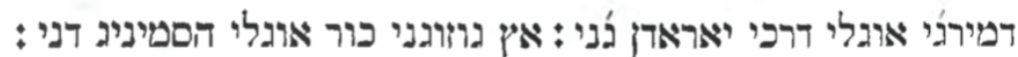

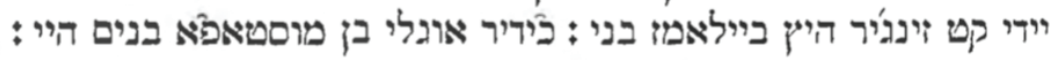

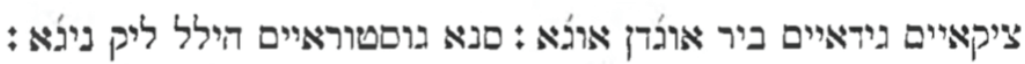

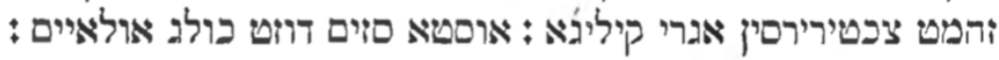

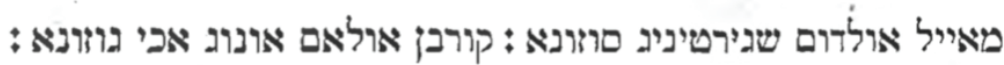

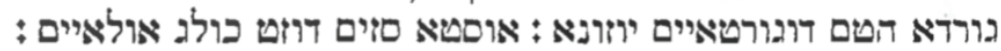

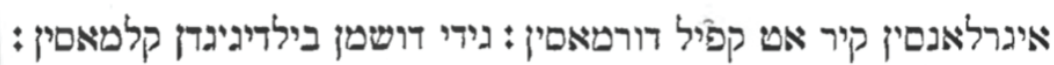

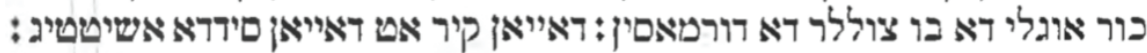

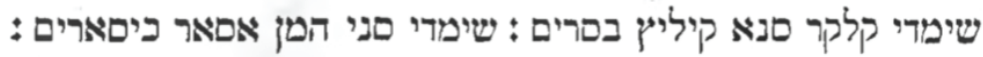

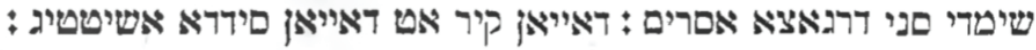

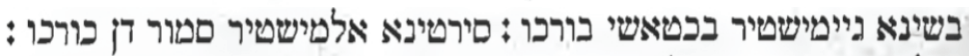

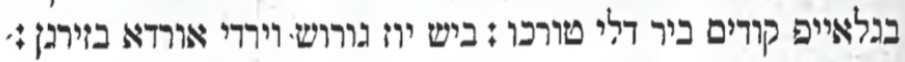
בינדים כוהלאייאן קיר אטיג םירטינא: אלירדים םמור דן בורכים אוסטומא:

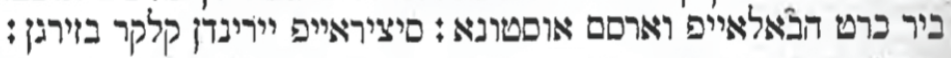

\section{2) KÖR OGLI}

Arap istan çöllerinde gizerken

Bana rras geldi gidi dört gidi

Biri Türkmen biri Laz birisi Arap

Geriden geleyir gidi dört gidi hey

Demirci oglı der ki yaradan canı

Aç gözüñni Kör oglı hasmınıñ danı

Yidi kat zincir hiç bilemez beni

Hıdır oglı ben Mustafa benim hey

Çıkayım gideyim bir ucdan uca Sana göstüreyim hilallik nice

Zahmet çektirirsiz ugrı kılıca

Usta sazım düzet kuluñ olayım 
Mayil oldum şegirtiniñ sözüne

Kurban olam onuñ eki gözüne

Görde hatam dogurtayım yüzüne

Usta sazım düzet kuluñ olayım

Igralansın Kir at kafil durmasın

Gidi düşman bildiginden kalmasın

Kör oglı da bu çöllerde durmasın

Dayan kır at dayan sıdda eşittiñ

Şimdi kalkar sana kılıç basarım

Şimdi seni heman asar kiserim

Şimdi seni daragaça asarım

Dayan kır at dayan sıdda eşittiñ

Başına giymiştir Bektaşi börkü

Sırtına almıştır samurdan kürkü

Bañlayıp kodım bir deli türkü

Biş yüz guruş virdi orda bezirgan

Bindim kühleyen kır atıñ sırtına

Alırdım samurdan börkim üstüme

Bir keret havalayıp varsam üstüne

Siçırayıp yerinden kalkar bezirgan 


\section{3 כור אוגלי}

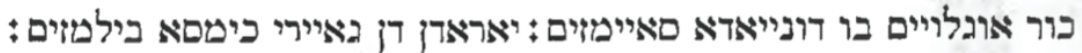

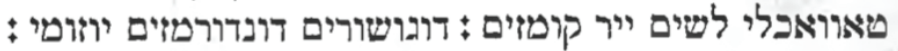

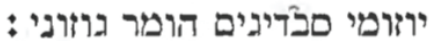

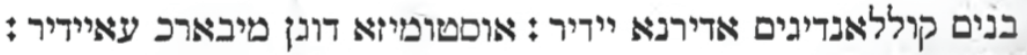

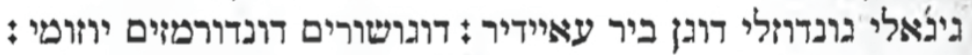

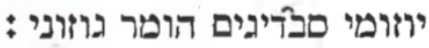

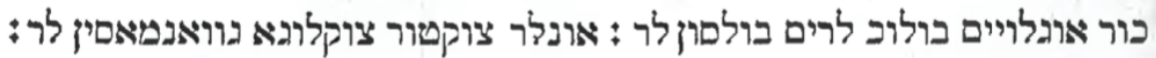

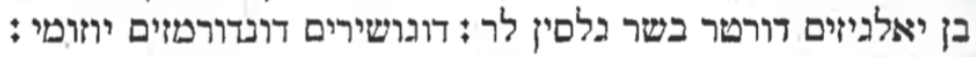

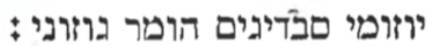

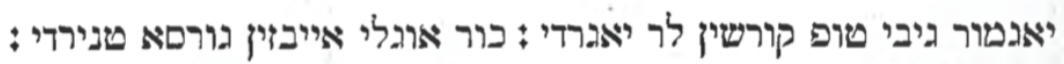

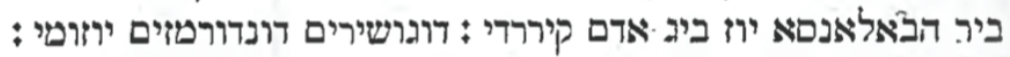

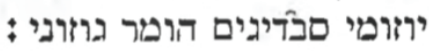

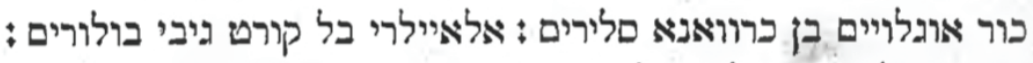

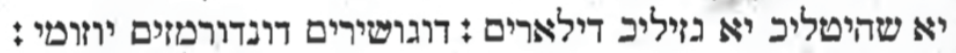

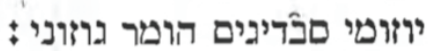

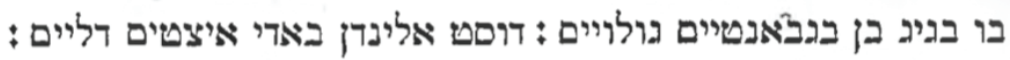

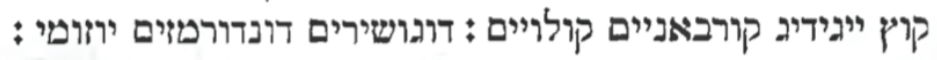

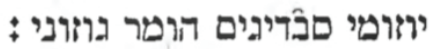

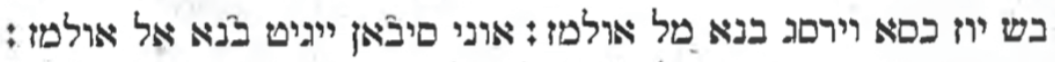

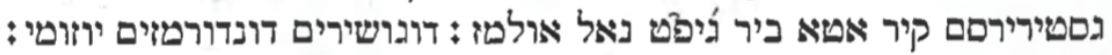

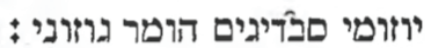

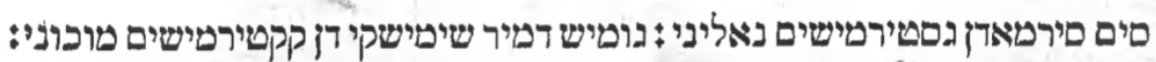

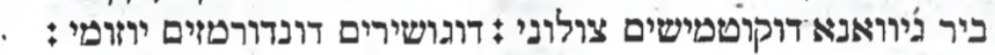
$17 *$

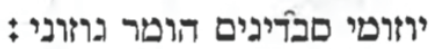

\section{3) KÖR OGLI}

Kör ogluyım bu dünyada saymazım

Yaradandan gayrı kimse bilmezim

Tevekli leşim yir komazım

Dögüşürim döndürmezim yüzümi

Yüzümi sevdigim humar gözüni 
Benim kullandigım Edirne yidir Üstümize döñen mibarek 'aydır

Giceli gündüzli dügün bir 'aydır

Dögüşürim döndürmezim yüzümi

Yüzümi sevdigim humar gözüni

Kör ogluyım bölüklerim bölsünler

Onlar çoktur çokluga güvenmesinler

Ben yalñızım dörter beşer gelsinler

Dögüşürim döndürmezim yüzümi

Yüzümi sevdigim humar gözüni

Yagmur gibi top kurşınlar yagardı

Kör oglı Ayvaz'1n görse tanırdı

Bir havalansa yüz biñ adam kırardı

Dögüşürim döndürmezim yüzümi

Yüzümi sevdigim humar gözüni

Kör ogluyım ben kervana salırım

Alayları bir kurt gibi bulurım

Ya şehitlik ya gazilik dilerim

Dögüşürim döndürmezim yüzümi

Yüzümi sevdigim humar gözüni

Bu bagıñ ben bagvantıyım gülüyim

Dost elinden badi içtim deliyim

Koç yigidiñ kurbanıyım kuluyım

Dögüşürim döndürmezim yüzümi

Yüzümi sevdigim humar gözüni

Beş yüz kise virseñ bana mal olmaz

Onı siven yigit bana el olmaz

Gestirirsem Kir ata bir cift nal olmaz

Dögüşürim döndürmezim yüzümi

Yüzümi sevdigim humar gözüni

Sim sırmadan gestirmişim nalını

Gümiş demir şımışkıdan kaktırmışım möküni

Bir civana dokutmışım çulunı

Dögüşürim döndürmezim yüzümi

Yüzümi sevdigim humar gözüni 


\section{4 כור אוגלי}

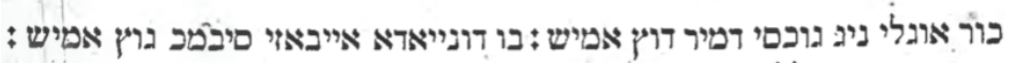

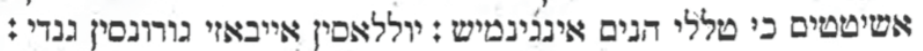

בנדן סלם אולסון בולי בגינא : יוללאםין אייבאזי גורוונסין גנדי :

בשינא "יקרים טכטי אילן טגי : יוללאסין אייבאי גיולי גורונסין גנדי :

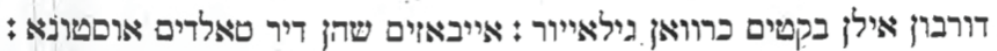

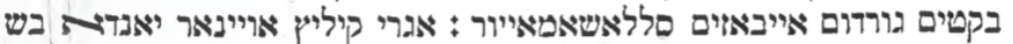
אילן:

וארי וירוג קויץ כור אוגלי אוייאן סין : איייאן סין דא סג אלינא דאיייאנסין:

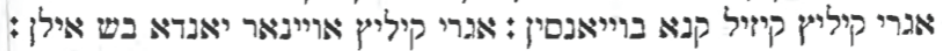

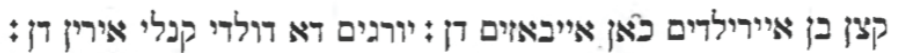
ייגיףיג איטטיגי גליר בשין דן : ציכם אגרי קיליץ דורט ביר יאנא דולאנםין:

\section{4) KÖR OGLI}

Kör oglunıñ göksi demir duç emiş

Bu dünyada Ayvaz'1 sivmek güç emiş

Eşittim ki Telli Hanım incinmiş

Yollasın Ayvaz’1 görünsin gendi

Benden selam olsun Bolı begine

Yollasın Ayvaz'1 görünsin gendi

Başına yıkarım tahtı ilen tacı

Yollasın Ayvaz'1 görünsin gendi

Dürbün ilen baktım kervan gileyor

Ayvaz'ım şahandır saldım üstüne

Baktım gördüm Ayvaz'ım sallaşamayor

Egri kılıç oynar yanda baş ilen

Vadi virüñ koç Kör oglı uyansın

Uyansın da sag eline dayansın

Egri kılıç kızıl kana boyansın

Egri kılıç oynar yanda baş ilen

Kaçan ben ayrıldım han Ayvaz'ımdan

Yüregim de doldı kanlı irinden

Yigidiñ ittigi gelir başından

Çikem egri kılıç dört bir yana dolansın 
25) בור אוגלי

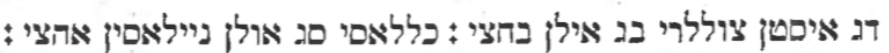

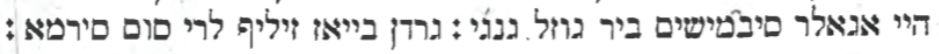

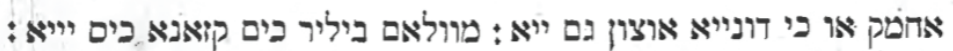

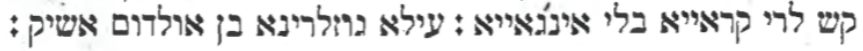

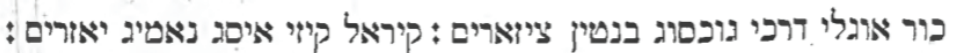

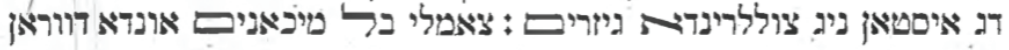

סוררים : איפופ

קיראל קיזי איםג דווראן םוראלים : צמלי בלא ואריפ טיכאן קוראלים :

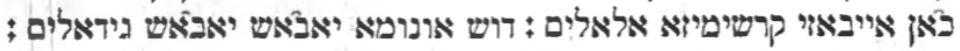

\section{5) KÖR OGLI}

Dagıstan çölleri bag ilen bahçi

Kellesi sag olan niylesin ahçi

Hey agalar sivmişim bir güzel genci

Gerdan biyaz zilifleri som sırma

Ahmak o ki dünya üçün gam yiye

Mevlam bilir kim kazana kim yiye

Kaşları karaya beli inceye

‘İla gözlerine ben oldum aşık

Kör oglı der ki göksüñ bentin çizerim

Kıral kızı iseñ namı̃̃ yazarım

Dagistannıñ çöllerinde gizerim

Çamlı bel mikanım onda devran sürerim

Kıral kızı iseñ devran sürelim

Çamlı bele varıp mikan kuralım

Han Ayvaz'ı karşımıza alalım

Düş önüme yavaş yavaş gidelim 


$$
\text { 26 בור אוגלי }
$$

בן ביר זמן צרדקלידא אוטורדים \$ דוסטים אניפ דושטנימי יאורדים:

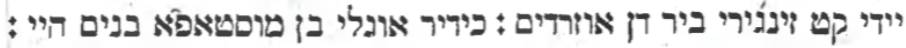

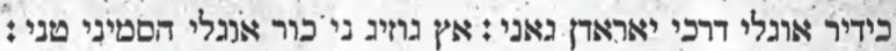

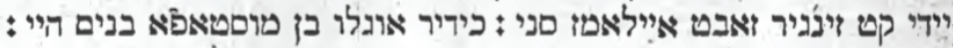

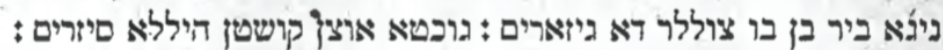
סגא סולא בקטם כללאג איורים : כידיר אוגלי בן טוסטאפטא בנים היי : אראבאטים ואר טיידנים ואר בוים ואר : שהאנים ואר אורדגיש ואר

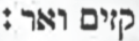

כור אוגלי אילן סללאשמאייא הזים ואר : כידיר אוגלי בן טוסטפא בנים היי :

\section{6) KÖR OGLI}

Ben bir zaman Çardaklıda oturdım

Dostım anıp düşmanımı yazardım

Yidi kat zinciri birden uzardım

Hıdır oglı ben Mustafa benim hey

Hıdır oglı der ki yaradan canı

Aç göziñni Kör oglı hasmını tanı

Yidi kat zincir zabt eylemez seni

Hıdır oglı ben Mustafa benim hey

Nice bir ben bu çöllerde gizerim

Gökte uçan kuştan hile sizerim

Saga sola bakmam kelleñ izerim

Hıdır oglı ben Mustafa benim hey

Arab atım var tiydanım var bezim var

Şahanım var ördegim var kazım var

Kör oglı ilen sallaşmaya hazım var

Hıdır oglı ben Mustafa benim hey 


$$
\text { 28) בור אוגלי }
$$

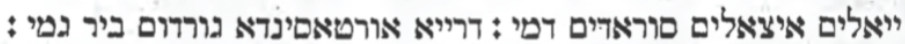

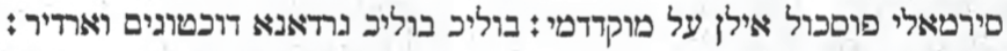

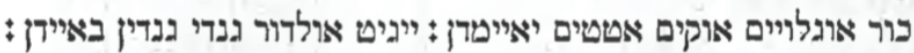

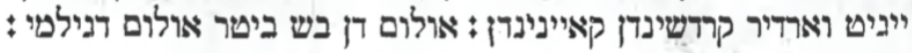

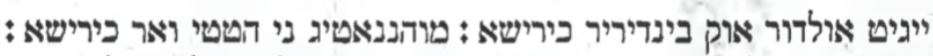
ביר ייגידיג אלי דגםא ריר אישא : ביג ייגיט טא קלקן אולורור סולטנים :

\section{8) KÖR OGLI}

Yiyelim içelim sürelim demi

Derya ortasında gördüm bir gemi

Sırmalı püskül ilen 'al mukaddedmi

Bölik bölik gerdana döktügim vardır

Kör ogluyım okım attım yaymadan

Yigit oldur gendi gendin bayidan

Yigit vardır kardaşından kaynından

Ölümden baş biter ölüm degilmi

Yigit oldur ok bindirir kirişe

Muhannetiñ ni hatti var kirişe

Bir yigidiñ eli degse bir işe

Biñ yigitte kalkan olur sultanım 


\section{0 בור אוגלי}

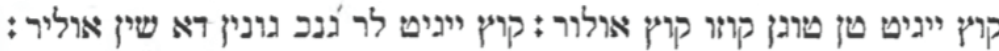

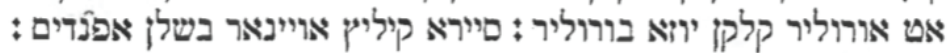

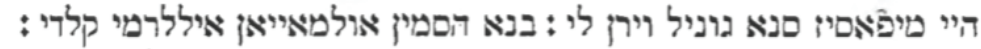

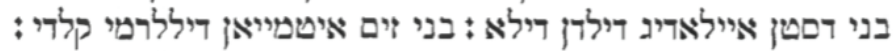

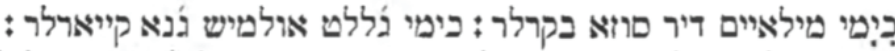

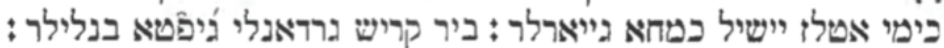

\section{0) KÖR OGLI}

Koç yigitten togan kuzu koç olur

Koç yigitler cenk güninde şin olur

At urulır kalkan yüze burulır

Sayra kılıç oynar başlan efendim

Hey mifasız sana gönil virenli

Bana hasmın olmayan iller mi kaldı

Beni dastan eylediñ dilden dile

Beni zim itmeyen diller mi kaldı

Kimi milayimdir söze bakarlar

Kimi cellat olmış cana kıyarlar

Kimi atlaz yişil kemha giyerler

Bir karış gerdanlı cifte benliler 


\section{1) בור אוגלי}

צמלי בלי בינזטטים בן ביזיםטאנא: גנדים דא בינגזארים ביר גניץ ארסלאנא :

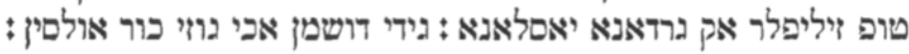

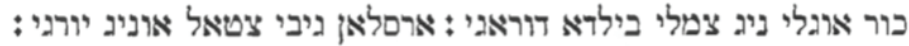
יאלן דן הו אידמו סיכר גירצאגי : גידי דושמן אכי גוזי פור אירואי אולםין:

כור אוגלי אונדה מיגלים קורמיש אוטורמיש : אלין דאכי באדיי דוסטה

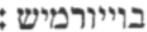

רושמן לרי סירא סירא דיוילמיש : גידי דושמן אכי גווי פור אולםין:

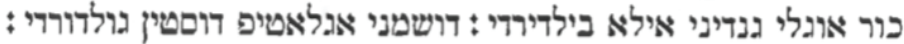
צמלי בילני ביזיםטאנא דונדורדי :גידי דושמן אכי גושי אמי כור אולםין :

\section{1) KÖR OGLI}

Çamlı beli binzettim ben bizistana

Gendimde binzerim bir genç arslana

Top zilifler ak gerdana yaslana

Gidi düşman eki gözi kör olsın

Kör oglınıñ çamlı belde duragı

Arslan gibi çatal oniñ yüregi

Yalandan haz idmez siver girçegi

Gidi düşman eki gözi kör olsın

Kör oglı onda miclis kurmış oturmış

Elindeki badi dosta buyurmış

Düşmanları sıra sıra dizilmiş

Gidi düşman eki gözi kör olsın

Kör oglı gendini ile bildirdi

Düşmanı aglayıp dostın güldürdi

Çamlı binli bizistana döndürdi

Gidi düşman eki gözi kör olsın 


\section{2}

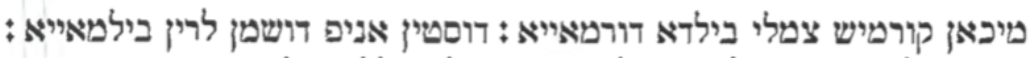

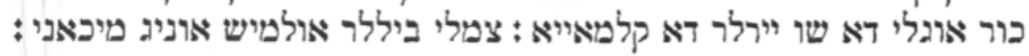

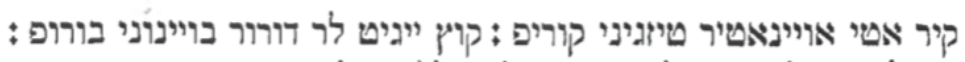

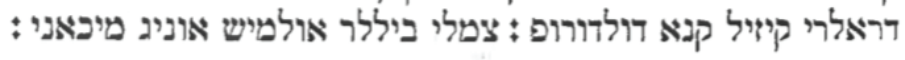

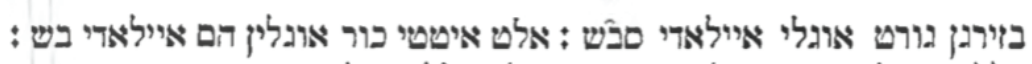

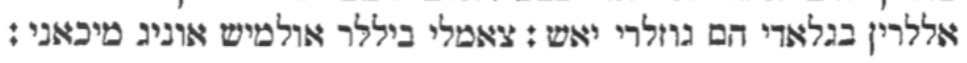

מוולא יארדימגיםי אילי ציוילדי : דראנאצא צכיל צילדי ייפי אוזולדי :

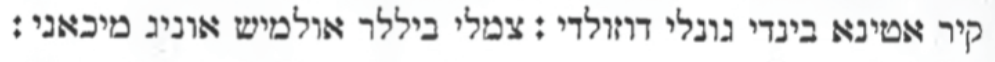

\section{2) KÖR OGLI}

Mikan kurmış çamlı bilde durmaya

Dostın anıp düşmanların bilmeye

Kör oglı da şu yirlerde kalmaya

Çamlı biler olmış onıñ mikanı

Kır atı oynatır tizgini kurıp

Koç yigitler durur boynunı burup

Deryaları kızıl kana doldurup

Çamlı biler olmış onıñ mikanı

Bezirgan Gürt oglı eyledi savaş

Alt itti Kör oglın hem eyledi baş

Ellerin bagladı hem gözleri yaş

Çamlı biler olmış onıñ mikanı

Mevla yardımcısı ili çizildi

Daragaça çekildi yipi üzüldi

Kır atına bindi gönli düzüldi

Çamlı biler olmış onıñ mikanı 


\section{3 בוף אוגלי}

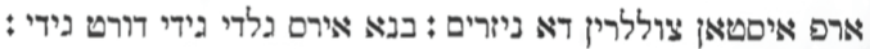

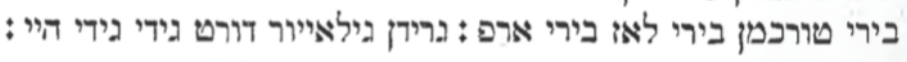

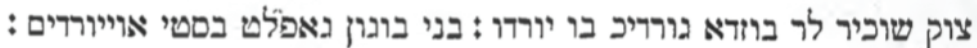

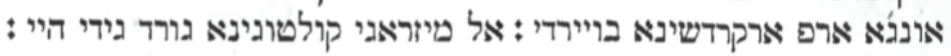

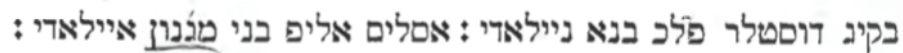

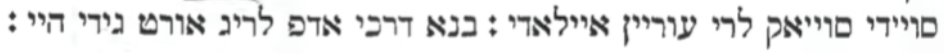

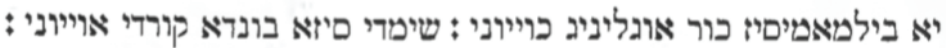

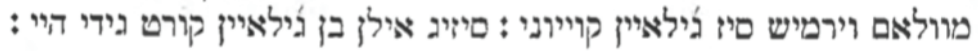

\section{3) KÖR OGLI}

Arap istan çöllerinde gizerim

Bana rras geldi gidi dört gidi

Biri Türkmen biri Laz biri Arap

Geriden gileyor dört gidi gidi hey

Çok şükirler bunda gördik bu yurdu Beni bugün gaflet bastı uyurdım Önce Arap arkardaşına buyurdı Al mızragı koltugına Gürd gidi hey

Bakıñ dostlar felek bana neyledi Aslı'm alıp beni Mecnun eyledi Soydı soyakları 'uryan eyledi Bana derki edepleriñ ört gidi hey

Ya bilmemisiz Kör oglınıñ huyunı Şimdi size bunda kurdı oyunı Mevlam virmiş sizcileyin koyunı Siziñ ilen bencileyin kurt gidi hey 


\section{Sonuç}

Türk dünyası anlatı geleneği göz önünde bulundurulduğunda yayılma alanı bakımından en çok çeşitliliğe uğramış epik anlatıların başında Köroğlu Destanı gelir. Bu bakımdan Köroğlu Destanı'nın çok geniş bir coğrafyaya yayılması yapılan çalışmaların da çeşitliliğini artırmıştır. Nitekim Köroğlu Destanı'nın Türk dünyası coğrafyasındaki yayılma ve genişleme süreci metin merkezli kuramlara yönelik araştırmaların da sorgulanmasına yol açmıştır. Belirtmemiz gerekir ki Türk dünyasının ortak düşün sisteminin ürünü olan Köroğlu destan ve hikâyeleri üzerine yeni bulgular ve yeni veriler ile daha bütüncül düzlemde yaklaşımın gerekliliği muhakkaktır.

Türk anlatı geleneğinde; herhangi bir halk bilgisi yaratmasının sözlü gelenek içerisinde bir yerden başka bir yere -sözlü veya yazılı bir şekilde- taşınabildiği ve bu taşınma esnasında anlatının kültürel bellekte çeşitlenme kazandığı pek çok halk bilgisi yaratmasında görülmektedir. Bunda şüphesiz ki Türk milletinin tarihsel süreç içerisinde savaş, göç, ticaret vb. olgular ile fiziksel ve zihinsel sınırlarını genişletmesinin payı büyüktür. Köroğlu destanı da böyle bir yayılma sonucunda Kırım Karay Türkleri arasında kendisine yer edinmiş ve Karay Türklerinin “mecuma” adını verdiği mecmualarda Köroğlu Destanı’nın izleri tespit edilmiştir. Bu çalışma ile birlikte de Kırım Karay Türkleri arasında varlığı tespit edilen 20 yeni şiir, İbrani harfli bir mecmuadan Latin harflerine aktarılarak Köroğlu hazinesine kazandırılmıştır.

\section{Notlar}

1 Köroğlu Destanı'nın yayılma sahası hakkında bkz. Pertev Naili Boratav, Köroğlu Destanı, İstanbul: Adam. 1984, ss. 21-44. Köroğlu kitabı, (S. Koz, Haz. 2014), İstanbul: Kitabevi.

\section{Kaynaklar}

Altınkaynak, E. (2006). Tozlu zaman perdesinde Kırım Karayları. Haarlem: Sota.

Boratav, P. N. (2011). Halk hikâyeleri ve halk hikâyeciliği. ( M.S. Koz, Haz.). İstanbul: Tarih Vakfi.

Boratav, P. N. (1984). Köroğlu destanı. İstanbul: Adam.

Köroğlu kitabı (2014). (S. Koz, Haz.). İstanbul: Kitabevi. 